\title{
E-Supervision Using Web: Elementary School Teachers' Reaction
}

\author{
G Habibi ${ }^{1}$, M Mandasari ${ }^{2}$, K Rukun $^{3}$ and Hadiyanto $^{4}$ \\ ${ }^{134}$ Universitas Negeri Padang, Padang City, West Sumatera, Indonesia. \\ ${ }^{2}$ Sekolah Tinggi Ilmu Administrasi LPPN Padang, Padang City, West Sumatera, Indonesia.
}

\begin{abstract}
The aim of this study is to analyze in depth the perceptions of teachers in Bukittinggi city towards e-supervision using web. This type of research is descriptive research. The sample of this study was all teachers at SD Al-Azhar Bukittinggi consisting of 28 people. The instruments of this study were interviews and questionnaires. The results showed that $75 \%$ of teachers positively responded the development of this e-supervision using web. There are some positive responds conducted by teachers. First, e-supervision using web can be done anywhere and anytime. It will be easier for the teachers to interact and discuss with the principal and colleagues about the problems faced in the learning process. Second, the principle announce and analyze the feedback on the results of instructional supervision effectively and steadily. Third, e-supervision is a good means to avoid miss-communication between principals and teachers in communicating the results of supervision, and fourth, teachers will get clear supervision results because of this systematic supervision which integrated with technology. In addition, e-supervision also faced several problems. First, the teachers is still face the difficulties in using technology devices, such as computer. Second, the lack of training to develop teachers' capabilities in implementing technology and information.
\end{abstract}

Key words: Instructional Supervision, E-supervision, Web, Teachers of Elementary School

\section{Introduction}

Education is the key to the development of a human civilization. This is in line with the national education goals in accordance with Law No. 20 of 2003 concerning National Education System article 3, namely: "developing skills and forming dignified national character and civilization in order to educate the nation's life, aiming to develop the potential of students to become believers and devoted to God Almighty, noble, healthy, capable, creative, independent and become a citizen of a democratic and responsible country ". On the other hands, education is one of the bases of the quality of human resources, in which this process not only increases the ability to think but also a qualified character so as to develop the potential of the human person as a whole. However, the problem of National Education which refers to the quality of education, especially the quality of students to date has not yet been completed to be resolved, the contributing factors are from many dimensions. One dimension of the causes of the weak quality of education comes from educators called teachers who have not optimally carried out their duties to become professional educators (Maswan and Muslimin: 2017).

This problem is also inseparable from the role of the principal in managing and assisting teachers in developing their professional abilities. As stated by Lele, et al. (2018), the success of education cannot be separated from the role of the principal as a supervisor in the field of education,

Copyright (C) 2019, the Authors. Published by Redwhite Press.

Page $\mid 25$

This is an open access article under the CC BY-NC license

(http://creativecommons.org/licenses/by-nc/4.0). 
which is to find educational problems and always fix the weaknesses that occur. In other words the success of an educational process is inseparable from the role of the principal as supervision where the principal must be able to analyze and find alternatives in solving problems found in the learning process at school. In more detail, the principal as a leader and supervisor has the authority and responsibility in developing education and all matters related to the teaching and learning process and curriculum and all its implementation. Furthermore, Arikunto (2011) asserts that principals are closer to the school environment and are even attached to school life which is more directed towards academic supervision. Based on this explanation, the principal is the right supervisor because he is closest and understands the conditions and needs of the school he leads. Beside that teacher professionalism can be developed with a planned, directed, and continuous supervision system so that it can create a good harmony in the education system.

Hence, supervision is an important factor in improving the quality of education. It is also emphasized by Sahertian (2010) that the development of teacher resources requires academic supervision assistance and the role of the principal in conducting academic supervision. It is also explained in Article 12 paragraph 1 of PP 28 of 1990 (Mulyasa, 2013) that principals are responsible for organizing educational activities, school administration, fostering other education personnel, and utilizing and maintaining infrastructure. Therefore, principals as leaders have an important role in the development of teacher professionalism both through training, learning opportunities but also provide motivation, improve discipline and provide guidance through supervision.

Previous research also suggested that academic supervision has the potential to improve classroom practice, and contribute to student success through professional growth and teacher improvement (Sergiovanni and Starratt: 2012). Appiah (2013) in its research conducted in Ghana also found that the need for effective supervision is now more important than before. Supervision is an effective method that can help achieving good results in the teaching and learning process. It means that it is very important for teaching and learning procedures to be continuously monitored and reviewed to ensure total achievement of goals. The same thing is also found by Campbell (2014) that the level of teaching arising from academic supervision carried out by the principal will ensure effectiveness that results in increased academic achievement of students in secondary schools in Ogun State, Nigeria. Furthermore, Adewele (2014) emphasizes that academic supervision and teaching are two activities that are closely related to the intention of developing teachers to a higher level of teaching competence. All indications, the internal academic supervision carried out by the principal is the best for improving the quality of learning and also maintaining higher standards due to ease of access, friendly relations with teachers for monitoring, correction and strengthening of ideas and innovations. Based on the explanation above, academic supervision is carried out in order to observe and assess the implementation of preparation and learning by the teacher and these two things cannot be separated. As explained by Glickman in Sudjana (2012) that academic supervision is a series of activities to help teachers develop their competencies in order to achieve learning goals.

But in fact, the principal in carrying out academic supervision is still experiencing problems. This is based on the results of observations made in several elementary schools (SD) in the city of Bukittinggi. Various obstacles encountered in the process of academic supervision both in the delivery technique and the intensity of the implementation of supervision carried out have not been well established so that principals are still incidental holding training to teachers in the learning process. In addition, school principals is lack of competencies that must be possessed to conduct training for teachers in the learning process. This is in accordance with the opinion of Arikunto (2011) who argues that in reality the principal has not been able to carry out supervision properly because the principal's workload is too heavy and their educational background is not in accordance with the supervised field of study. So that the purpose of fostering and guiding the teacher is still not perfect and the teacher does not understand the meaning of the importance of supervision carried out by the principal. In general, Widodo (2016) in his research concluded that the implementation of supervision by school supervisors in Indonesia is still far from the theory of supervision.

Therefore, increasing academic supervision requires support and assistance from various components of education, especially in responding to the challenges of the XXI century which are 
very closely related to technology or which is now referred to as the 4.0 industrial revolution era, where the digital industry has become a paradigm reference in the current order of life. In other words, teaching and development of basic skills are currently moving towards the evolution of virtual learning environments to support classroom education with certain educational activities based on elearning. Thus, schools quickly migrate to online environments, and supervision practices must adapt to changing educational landscapes (Smith et al., 2016). This phenomenon is something that is inevitable, but also becomes a new opportunity so that Indonesia needs to prepare itself. The basis of this era is digitalization by using comprehensive data analysis as a result new literacy is needed besides old literacy (Suwardana, 2017). Moreover, education supervision must also deal with the restructuring of resource and network technology, not only to develop their role as supervisors, but also to understand how to apply the correct supervision process in a very digital context (Zapeda, 2013). In conclusion, the use of technology is expected to facilitate the task of the principal as an academic supervisor. In addition, supervisory practices need to be adapted to the online learning environment, the trend towards virtualization education certainly requires new ways to monitor, control, advise, and guide the entire school community for the development of effective and appropriate interactive models and virtual training.

Currently online supervision can be said as a new supervision technique in West Sumatra in particular. The benefits and facilities available are one of the reasons for online supervision. One form of online supervision is the Web. The web-assisted academic supervision model is developed to overcome several challenges in the implementation of academic supervision such as the large number of assisted teachers and distant geographical location. Web-based supervision offers several supervision practices using web-based internet technology assistance, building communication and virtual communities between staff and assisted teachers (Valerie, 2012). This academic supervision model will certainly assist the implementation of supervision in conducting guidance and training for teachers to improve their competence. As Chan (2010) said that the use of high technology for academic supervision is an alternative in overcoming the problem of implementing academic supervision. Guntoro et al. (2016) also emphasized that web-based applications offer a way of communicating and getting information using world wide web technology with the aim of providing teaching, guidebooks, rich material, and collaborative learning that can be accessed at any time. Based on this explanation, academic supervision online by using this web is one of the things that needs to be developed to improve the quality of academic supervision carried out by the principal. However, the success of web-based e-supervision is inseparable from the teacher's ability to use it optimally. Therefore, the purpose of this study was to analyze in depth how the teacher's perceptions of webbased e-supervision were carried out at Al-Azhar Private Elementary School in Bukittinggi, West Sumatra.

\section{Research Methodology}

The type of this research was descriptive. The population in this study were 28 teachers of AlAzhar Private Elementary School. Since a population is less than 100, so that this research does not do the sampling technique. To obtain the data needed in this study, the instruments of this researcher were questionnaires and interviews. Data analysis techniques carried out are presented in the form of a percentage table then analyzed qualitatively, namely interpreting data that has been systematically compiled and then taken conclusions. Lastly, the data is analyzed quantitatively using percentage analysis.

\section{Results and Discussion}

Data from this study were collected through questionnaires and interviews. The questionnaire of this study consisted of several indicators, namely looking at the perceptions of elementary school teachers in general regarding e-supervision using web started from planning, process and result. Twenty-eight questionnaires were distributed to all teachers of Al-Azhar private elementary school. 
Each statement in the questionnaire uses Likert-scale and the data is tabulated and analyzed using the Statistical Package for Social Sciences (SPSS).

Based on the first indicator in general, $75 \%$ of teachers at Al-Azhar private elementary school positively welcomed the use of e-supervision by using the web in their school. This is also supported by the results of interviews where almost all teachers welcomed e-supervision using web for principals in providing guidance and supervision in the learning process. Furthermore, this study also analyzed the elementary school teachers' perception of the mode of e-supervision using web. In more detail, the results of this indicator are explained in the table below.

Table 1. Elementary School Teachers 'Perception of the Mode of E-Supervision Using Web

\begin{tabular}{|c|c|c|c|c|c|}
\hline $\begin{array}{l}\text { The Mode of E-Supervision Using } \\
\text { Web }\end{array}$ & $\begin{array}{c}\text { Strongly } \\
\text { agree }\end{array}$ & Agree & No idea & Disagree & $\begin{array}{l}\text { Strongly } \\
\text { disagree }\end{array}$ \\
\hline Creates excitement in teachers & $71.3 \%$ & $25.2 \%$ & - & $3.5 \%$ & - \\
\hline $\begin{array}{l}\text { Focus mostly on teachers' } \\
\text { profesionalism }\end{array}$ & $40 \%$ & $60 \%$ & & & \\
\hline $\begin{array}{l}\text { It is democratic rather than } \\
\text { authorative }\end{array}$ & $67.3 \%$ & $30.5 \%$ & $2.2 \%$ & - & - \\
\hline $\begin{array}{l}\text { It is more 'looking for errors' and } \\
\text { critical }\end{array}$ & $12.4 \%$ & $86.8 \%$ & - & $0.8 \%$ & \\
\hline $\begin{array}{l}\text { Includes sharing } \quad \text { mutual } \\
\text { responsibilities and participation } \\
\text { between teachers and supervisor }\end{array}$ & $67 \%$ & $33 \%$ & - & - & - \\
\hline Puts the teacher under pressure & - & $8.3 \%$ & - & $89 \%$ & $2.7 \%$ \\
\hline It is easy to use & $25 \%$ & & - & & \\
\hline $\begin{array}{l}\text { Damage my confidence and } \\
\text { effectiveness }\end{array}$ & - & - & - & $98.5 \%$ & $1.5 \%$ \\
\hline The feedback is clear and superficial & $27 \%$ & $73 \%$ & - & - & - \\
\hline $\begin{array}{l}\text { The evaluation reports carefully and } \\
\text { quickly }\end{array}$ & $7.3 \%$ & $89.5 \%$ & - & $3.2 \%$ & \\
\hline
\end{tabular}

Based on the data obtained from table 1 above, it can be explained that e-supervision using the web provides its own color for the teacher in the process of supervision carried out by the principal. Almost all teachers feel challenged to use this e-supervision using web. Besides that from the teachers' point of view, this e-supervision based web also helps teachers to develop their professionalism in learning. This is because this kind of e-supervision is also equipped with a learning menu where the teacher can learn about 2013 curriculum as a whole both from the learning model to its development. It can be proven based on the result of interview, the teachers also stated that e-supervision using web helped them to develop their ability to understand the learning model in $\mathrm{k}-13$, besides that the discussion or chat menu in the forum also provided and it made the teacher easier to discuss and share information, both fellow teachers and headmaster, this can be done every time and every where. So, the practicality of e-supervision using web is one of the supervision technique that is beneficial for teachers in increasing their professionalism. This is in line with what was explained by Masaong (2012), improving the quality of learning and teacher professionalism is closely related to the effectiveness of supervision services. In addition, the use of e-supervision using this web also changes the way of teachers' view toward supervision. As revealed by Marwan (2017), supervision is considered solely to find fault. However, the teacher stated that the system of e-supervision process is not an inspection or judgment of them but as a container to solve the problems that they face in the learning process.

Furthermore, the results of supervision according to teacher perceptions in e-supervision using this web are clear and detailed. The teacher believes that the feedback they get is very clear, concise and fast. This makes the teacher able to solve the problems they encounter in the learning process. In addition, the feedback provided is also in personally way, it means that only the related teacher can see 
the results of their academic supervision. In other words, e-supervision makes good communication between principals and teachers personally so that there is no miss-communication or discomfort in giving criticism and suggestions in relation to the academic supervision process. This makes esupervision using web has its own value because in terms of privacy and this way of informing the results of supervision do not make the teacher lose their self-confidence or make them feel humiliated for being criticized or evaluated.

Besides, based on practicality of using this e-supervision there are differences from senior and junior teachers. Senior teachers who are above 40 years old on average feel the use of e-supervision makes them a little worried because they are still not fully technologically literate and during the process of using the teacher feel they are still experiencing problems, such as being confused with the available menu options. This is also supported by the results of interviews, these teachers were still hesitant in implementing this e-supervision using web. The use of technology, especially computers and the internet, is a new thing for them, but this is certainly different from the use of computers. They also argued that the socialization of the use of technology and information in the world of education, especially in the millennial era, also called revolution 4.0, must be supported by training facilities, especially for senior teachers. However, for junior teachers who are above the age of 25 on average, the use of web-based e-supervision is not an obstacle for them. Because the web is not something new for them. Husain (2014) also found that one of the problems in implementing technology and information in the world of education is the lack of teacher competence in utilizing the information technology that has been provided, one of which is influenced by age. In general, the results of a survey conducted by the Ministry of Culture and Communication Technology and Communication Center in December 2018 concluded that only $40 \%$ of teachers were ready with technology. Based on the results of the study it can be concluded that the implementation of e-supervision using web is a new innovation, especially at Al-Azhar Private Elementary School itself and the teacher as a whole welcomes with this kind of supervision.

\section{Conclusion}

Professional teachers are the basis of an education in this millennial era. One of the means in developing teacher professionalism is the process of supervision carried out by the principal. The era of 4.0 which is full of the charm of the use of technology and information brings changes in the form of supervision where this era leads to online-based supervision called e-supervision by using web. The teacher as a person involved in the supervision process carried out by this principal certainly has their own perceptions and views on e-supervision using this web. The results of this study provide that teachers welcome the use of e-supervision. The teacher argues that e-supervision using this web makes them change the way of their point of view toward the process of supervision, where supervision is not a process of finding fault but rather helps them in developing professionalism in the learning process. In addition, this web-based e-supervision process is very helpful for them in sharing information and communicating with each other between teachers and principals. Furthermore, the results of supervision are also personal, clear, and easy to understand. So that the teacher does not feel intimidated and this will not reduce the teacher's self-confidence. However, in addition to the positive response to e-supervision there are several problems that are still found, such as the lack of teachers 'ability to use ICTs and the lack of government efforts in developing teachers' abilities in this field.

\section{References}

[1] Adewale, Solomon Orenaiya. 2014. Instructional Improvement of Secondary School Teachers through Effective Academic Supervision by the Vice-Principals. Journal of Education and Human Development. June 2014, Vol. 3, No. 2. 
[2]Appiah, M. R. 2013. A study of supervision in rural and urban junior high schools in the AkuapimNorth district.

[Online] http://www.ir.ucc.edu.gh/dspace/bitstream/123456789/..../APPIAH\%202009\%202.pdf Retrieved on 18th February 2013.

[3] Arikunto, Suharsimi. 2011. Dasar-dasar Supervisi, Jakarta: PT. Rineka Cipta, 2004.

[4] Campbell, J.M. 2014. Resources for professional supervision and clinical supervision. A handbook for practioners. Authored by J.M Campbell published in 2004.

[5] Chan, S.C.H. \& Ngai, E.W.T. 2010. A Qualitative Study Of Information Technology Adoption: How Ten Organizations Adopted Web-Based Training.Journal Department of Management. Blackwell Publishing No 17: 289-315.

[6] Guntoro, David., Sumaryanto, Totok., Rifai, Ahmad., 2016. Pengembangan Model Supervisi Akademik Berbantuan E-Supervision Berbasis Web. Educational Management Journal.

[7] Husain, Chaidar. 2014 "Pemanfaatan Teknologi Informasi dan Komunikasi dalam Pembelajaran di SMA Muhammadiyah Tarakan”, Jurnal Kebijakan dan Pengembangan Pendidikan, Volume 2, Nomor 2 (Juli 2014), 189.

[8] Lele.D.M, Setiawan.D, Sulhadi. 2018. Clinical Supervision Instrument Development for Junior High School Teacher Based on Android. Journal of Educational Research and Evaluation. JERE 7 (1).

[9] Marwan. 2017. Pengaruh Pemanfaatan Teknologi Informasi dan Pelaksanaan Supervisi Kelas Terhadap Kinerja Guru Pendidikan Agama Islam di SMA Se Kota Palu Tahun 2017. Thesis. Unpublished.

[10] Masaong, Kadir. 2012 Supervisi Pembelajaran dan Pengembangan Kapastas Guru; Memberdayakan Pengawas Sebagai Gurunya Guru, Bandung: Alfabeta.

[11] Maswan \& Khoirul Muslimin. 2017. Teknologi Pendidikan Penerapan Pembelajaran yang Sistematis, Pustaka Pelajar: Yogyakarta.

[12] Mulyasa, E. 2013. Menjadi Kepala Sekolah Profesional, Bandung; PT. Remaja Rosdakarya.

[13] Rutherford, J. 2004. Technology in the schools. Technology in Society, 26, 149-160.

[14] Sahertian, Piet A. 2010. Konsep Dasar dan Tekhnik Supervisi, Jakarta: Rineka Cipta.

[15] Sergiovanni, T.J. \& Starratt, R.J. 2012. Supervision: A redefinition. Boston, M.A: Mc GrawHill.

[16] Smith, R., Clark, T., \& Blomeyer, R. 2006. New Research on K-12 Online Learning: Implications for Teacher Education. As cited in C. Crawford et al. (Eds.), Proceedings of Society for Information Technology and Teacher Education International Conference 2006.

[17] Sudjana, N. 2012. Pemantauan Pelaksanaan Standar Nasional Pendidikan (Panduan Bagi Pengawas Sekolah). Jakarta: Bina mitra.

[18] Suwardana, Hendra., 2017. Revolusi 4.0 berbasis Revolusi Mental. Jurnal Jati Unik. Vol 1. No.2

[19] Valerie, L. 2012. Online Supervision of Field Education. International Journal Field Educator Simmon School of Social Work, Vol.2(1):215-219.

[20] Widodo, J. 2007. Supervisi Guru Mata Pelajaran Ekonomi di Indonesia : Antara Teori dan Realita. Jurnal Pendidikan Ekonomi, 2(2), 291-313.

[21] Zapeda, S. J. 2007. Instructional Supervision Applying Tools and Concepts. Larchmont, NY: Eye on Education. 